\title{
The Fine Structure of Eadie's Ovals Isolated from Sheep Rumen
}

\author{
By E. A. MUNN AND C. G. ORPIN \\ Biochemistry Department, Agricultural Research Council, \\ Institute of Animal Physiology, Babraham, Cambridge CB2 $4 A T$
}

(Received 9 December 1974; revised 24 April 1975)

SUMMARY

The structure of two strains of the Gram-negative rumen organism, Eadie's Oval, was examined with the electron microscope. Despite their large size, their fine structure indicated that they were bacteria. They had a cell envelope consisting of two membranes separated by a dense layer which could be solubilized by lysozyme. They possessed characteristic bacterial flagella, and lacked internal organization with ribosomes and DNA-like material dispersed throughout the cytoplasm.

The outer membrane was corrugated and each strain had a characteristic pattern of corrugations. One strain had sheathed flagella, the other did not. Both strains were coated with fibrils up to $660 \mathrm{~nm}$ long, but which apparently contracted to give an unusual cross-banded layer when treated with lysozyme.

\section{INTRODUCTION}

Two ovoid, motile, Gram-negative organisms, which occur in the rumen of sheep, goats and cattle, are known colloquially as 'Ovals'. Neither has been fully characterized or allocated a taxonomic position or scientific name, and the relationship of the one to the other is not known. The smaller of the two has maximum axial dimensions of 2.5 to $3.0 \mu \mathrm{m}$ by $4^{\circ} \circ$ to $9 \cdot 0 \mu \mathrm{m}$ (Hungate, I966) and was originally described by Woodcock \& Lapage (I9I3), who thought that it was similar or identical to Selenomonas ruminantium. Quin (I943) proposed that it was a yeast, but this was rejected by McGaughey \& Sellers (1948) and van der Westhuizen, Oxford \& Quin (I950). Wicken \& Howard (1967) found diaminopimelate and muramic acid in the cell walls of this organism, now known by the colloquial name of Quin's Oval (Q.O.), and therefore concluded that it was a bacterium. The other Oval was first described by Eadie (1962); it has average axial dimensions of $8.5 \times 12.2 \mu \mathrm{m}$ (Orpin, 1972) and thus is substantially larger than Quin's Oval. It has been observed in ruminants in several countries (Eadie, 1962; Abou Akkada \& El-Shazly, 1964; Warner, I962, 1966; Orpin, 1972). Quin (1943) in South Africa also mentioned the presence of oval organisms larger than the ones which are now given his name, but gave no details. The photomicrograph he presented of Quin's Oval appears, in fact, to be of a mixed population containing both Quin's and larger Ovals, possibly the same as those described by Eadie (1962), and which have subsequently been referred to as Eadie's Ovals (E.O.). This organism has been observed in the rumen of $90 \%$ of the sheep we have examined, in populations ranging from $4.5 \times 10^{5}$ to $\mathrm{I} \cdot \mathrm{I} \times 10^{8} / \mathrm{ml}$, and appears to be a normal member of the rumen microbial population. Light microscopy of living and stained organisms has shown that E.O. is probably a bacterium, despite its large size (Orpin, 1972). This contention is supported by the results presented in this paper in which we describe the fine structure of two strains of E.O. which were first distinguished on the basis of differing substrate utilization patterns (Orpin, 1972). 


\section{METHODS}

Isolation, culture and harvesting. The E.O. used were those strains isolated and cultured by Orpin (1972). Cells were harvested from the culture medium, which consisted of $10 \%$ (v/v) autoclaved rumen fluid supplemented in the salts and glucose (Orpin, 1972) by centrifugation in a salts solution under $\mathrm{CO}_{2}$.

Preparation of 'starved' E.O. Suspensions of freshly harvested E.O. were incubated for $48 \mathrm{~h}$ at $39{ }^{\circ} \mathrm{C}$ under $\mathrm{CO}_{2}$ in the culture medium salts solution, with the omission of rumen fluid and glucose. The cultures were centrifuged at $1000 \mathrm{~g}$ for $5 \mathrm{~min}$ and resuspended in the salts solution omitting the sodium bicarbonate.

Lysozyme treatment. Freshly harvested E.O. (approximately $2 \mathrm{mg}$ dry wt) were suspended in $5.0 \mathrm{ml}$ of $50 \mathrm{mM}$-potassium phosphate buffer $\mathrm{pH} 7.0$, and $0.5 \mathrm{ml}$ of lysozyme solution $(5 \mathrm{mg} / \mathrm{ml})$ was added. The reaction mixture was incubated at $39{ }^{\circ} \mathrm{C}$ for $\mathrm{I} \mathrm{h}$, and the E.O. sedimented by centrifugation at $1000 \mathrm{~g}$ for $5 \mathrm{~min}$, washed twice by centrifugation in $50 \mathrm{mM}$ phosphate buffer $\mathrm{pH} 7.0$ and resuspended in the same buffer. Some cell suspensions $(2 \mathrm{mg}$ dry wt) were also pre-incubated at $39^{\circ} \mathrm{C}$ for $10 \mathrm{~min}$ in $5 \mathrm{ml}$ of $50 \mathrm{~mm}$-tris- $\mathrm{HCl}$ buffer $\mathrm{pH} 7.4$ containing $5 \mathrm{mg}$ trypsin, centrifuged at $1000 \mathrm{~g}$ for $5 \mathrm{~min}$, washed twice in $50 \mathrm{~mm}$-tris- $\mathrm{HCl}$ buffer $\mathrm{pH} 7 \cdot 4$, resuspended in $50 \mathrm{mM}$-phosphate buffer $(5 \mathrm{ml})$, and treated with lysozyme as above.

Extraction with chloroform-methanol. Eadie's Ovals ( $2 \mathrm{mg}$ dry wt) were shaken for $15 \mathrm{~min}$ at $18{ }^{\circ} \mathrm{C}$ with $5 \mathrm{ml}$ chloroform-methanol $(2: \mathrm{I}, \mathrm{v} / \mathrm{v})$. The suspension was centrifuged at $2500 \mathrm{~g}$ for $5 \mathrm{~min}$, the supernatant decanted, and the precipitate was washed twice by centrifugation in methanol, twice in $50 \mathrm{~mm}$-potassium phosphate buffer $\mathrm{pH} 7.0$, and resuspended in the same buffer.

Extraction with sodium dodecyl sulphate. Eadie's Ovals ( $2 \mathrm{mg}$ dry wt) were suspended in $5 \mathrm{ml}$ of $50 \mathrm{~mm}$-potassium phosphate buffer $\mathrm{pH} 7 \cdot 0$, containing $5 \%(\mathrm{w} / \mathrm{v})$ sodium dodecyl sulphate. The suspension was shaken at $18{ }^{\circ} \mathrm{C}$ for $30 \mathrm{~min}$, and the E.O. sedimented by centrifugation at $2500 \mathrm{~g}$ for $5 \mathrm{~min}$. The pellet was washed twice by centrifugation in buffer under the same conditions and resuspended in the same buffer.

Electron microscopy. For thin sectioning, suspensions of the organisms were fixed with glutaraldehyde buffered with 50 mM-sodium cacodylate $\mathrm{pH} 7 \cdot 4$ for I to $2 \mathrm{~h}$ at room temperature, then 2 to $\mathrm{I} 5 \mathrm{~h}$ at $4{ }^{\circ} \mathrm{C}$. A range of concentrations of glutaraldehyde, from 0.6 to $4 \%(\mathrm{v} / \mathrm{v})$, was tested. At concentrations greater than $3 \%$ the cells were deformed and their contents contracted away from the surface layers. All the electron micrographs of sections presented here were obtained from preparations fixed with either 0.8 or $\mathrm{I} \cdot 0 \%$ glutaraldehyde. Samples were centrifuged for $30 \mathrm{~s}$ in an Eppendorf 3200 centrifuge (at I5000 r.p.m.) and the pellets resuspended in cold $0.2 \mathrm{M}$-sodium cacodylate for $30 \mathrm{~min}$. This process was repeated twice and the organisms finally resuspended in $\mathrm{I} \%$ osmium tetroxide in $\mathrm{O} . \mathrm{I} \mathrm{M}$ sodium cacodylate for $2 \mathrm{~h}$ at $4{ }^{\circ} \mathrm{C}$. The samples were dehydrated with a graded series of ethanol solutions, transferred to propylene oxide and embedded in Araldite. Sections were stained with lead citrate and uranyl acetate.

Specimens were negatively stained with $2 \%(\mathrm{v} / \mathrm{v})$ sodium phosphotungstate $\mathrm{pH} 7 \cdot 2$; some samples were fixed with $2 \%$ glutaraldehyde before negative staining. 

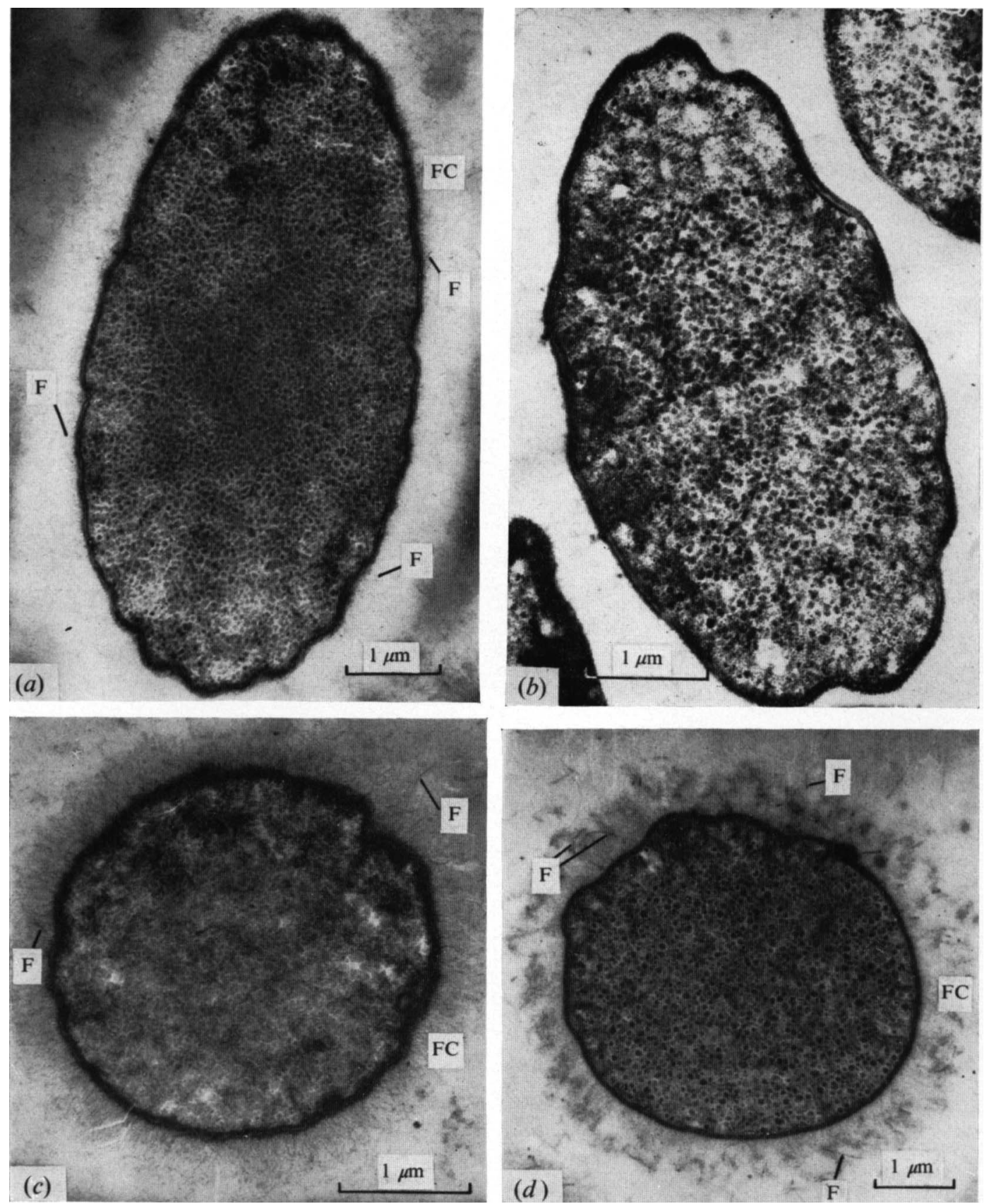

Fig. I. Longitudinal $(a, b)$ and transverse $(c, d)$ sections of strain-I $(a, c)$ and strain-2 $(b, d)$ Eadie's Ovals, showing the overall shape of the cells, the flagella (F), the presence of the fibrous coat (FC) and the orientation of the corrugations in the outer membrane. 

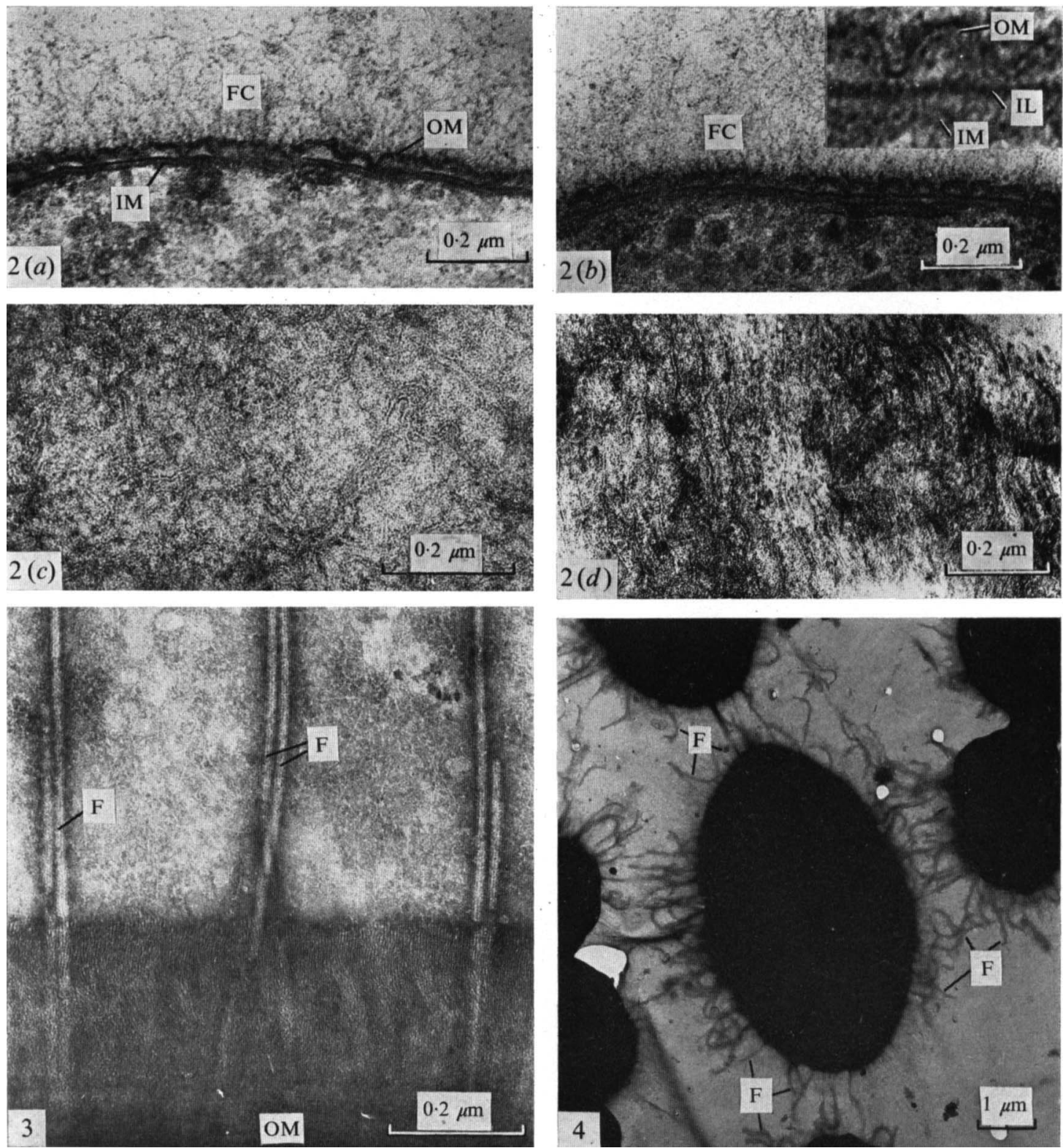

Fig. 2. Sections showing the components of the cell envelope of strain-1 $(a, c)$ and strain-2 $(b, d)$ Eadie's Ovals. In $(a)$ and $(b)$ the membranes are perpendicular to the plane of the section. In $(c)$ and $(d)$ the membranes are in the plane of the section. OM, outer membrane; IL, dense intermediate layer; IM, inner membrane; FC, fibrous coat to outer membrane. The inset in $(b)$ is $4 \times$ the field. Fig. 3. Negatively stained Eadie's Oval (strain 2) showing the fibrils coating the outer membrane $(\mathrm{OM})$ which can just be discerned at the bottom of the electron micrograph. F, flagella.

Fig. 4. Negatively stained Eadie's Oval (strain 2), showing the peritrichous distribution of the flagella (F). 

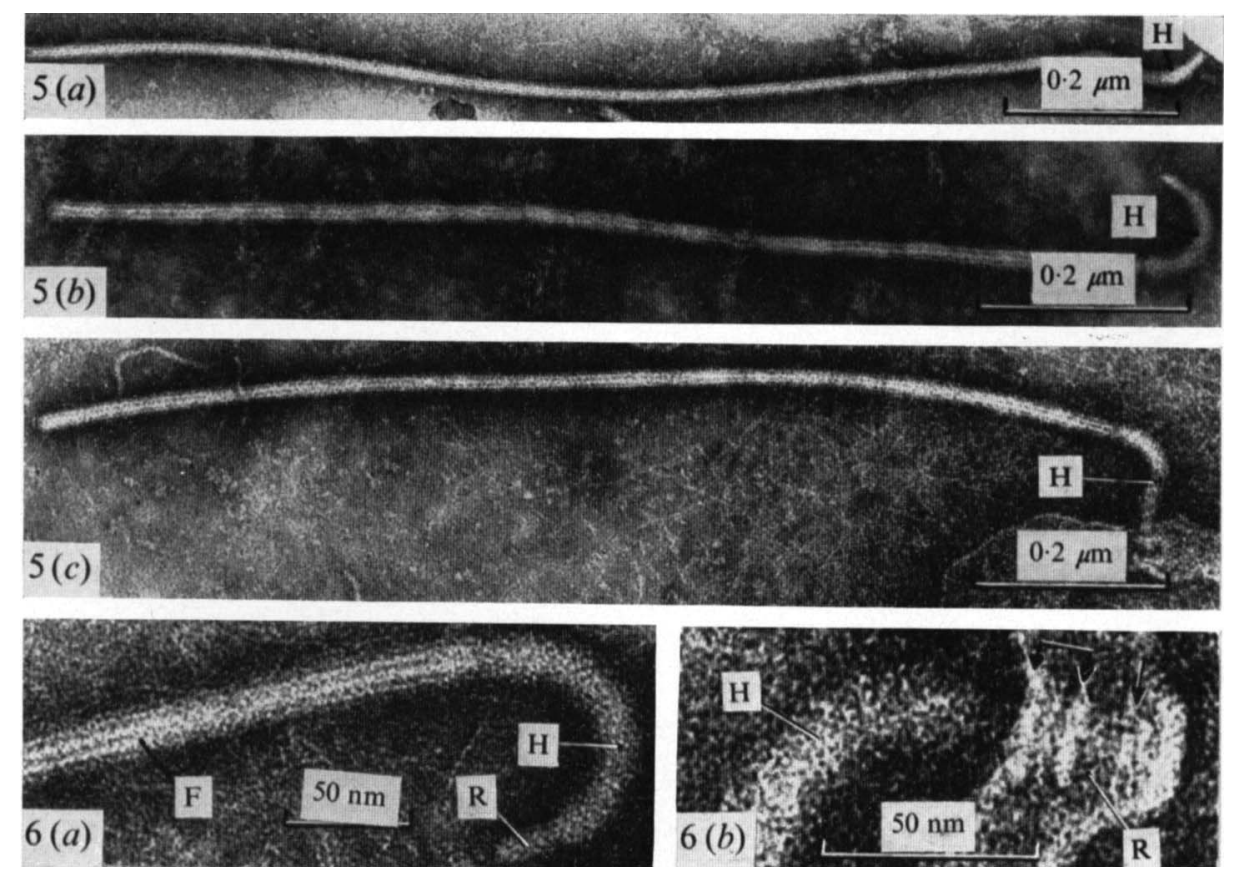

Fig. 5. Negatively stained flagella from Eadie's Ovals. Each flagellum terminates in a basal hook (H) with a surface pattern distinct from that of the rest of the flagellum.

Fig. 6. Negatively stained basal hooks. (a) On a detached flagellum; (b) part of a hook attached to a fragment of cell envelope. The basal hook $(\mathrm{H})$ is continuous with a rod $(\mathrm{R})$ which passes through a double annulus, seen edge on (joined arrows) in $(b)$, and terminates in another annular structure (single arrow).

\section{RESULTS}

There was little difference in the overall appearance of the two strains of E.O. (Fig. I), but they could be distinguished by the form of their outer membrane and by the presence or absence of flagella sheaths.

\section{The cell envelope}

The cell envelope, as seen in sections, consisted of three components, an outer membrane which was extensively corrugated, a dense intermediate layer and an inner membrane; this arrangement is commonly found in Gram-negative bacteria, and by analogy we will call the inner membrane the plasma membrane. The corrugations of the outer membrane were 25 to $35 \mathrm{~nm}$ deep. In strain-I Ovals they were of irregular width (Figs. $2 a$ and 8) in the range 30 to $150 \mathrm{~nm}$; in strain 2 the corrugations were more regular in width (Fig. $2 b$ ), 40 to $60 \mathrm{~nm}$ centre-to-centre depending on the cell, and were aligned approximately parallel to the long axis of the cell. The differences in arrangement of the corrugations were obvious in sections in which the outer membrane lay in the plane of the section (Fig. 2c,d) and in negatively stained preparations.

The dense intermediate layer was smooth and about $4 \mathrm{~nm}$ thick; it paralleled the course of the plasma membrane, from which it was separated by a space 30 to $70 \mathrm{~nm}$ wide. In preparations in which the cell contents were 'shrunken' (e.g. when the concentration of glutaraldehyde was $3 \%$ or greater), the plasma membrane pulled away from the dense 

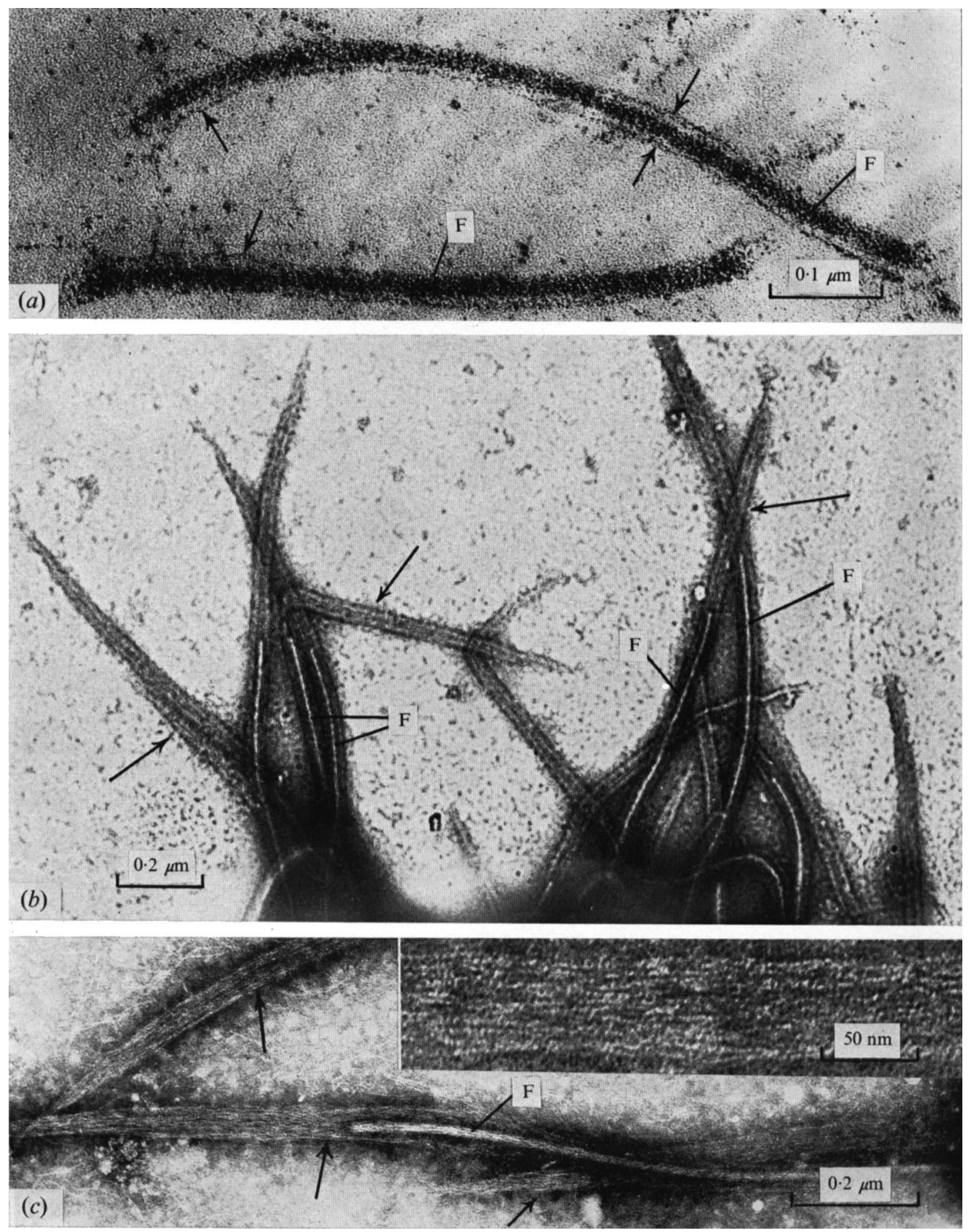

Fig. 7. Section (a), and negatively stained preparations ( $b$ and $c$ ), showing the sheaths (arrows) around and extending beyond the flagella (F) of strain-2 Eadie's Ovals. The inset in $(c)$ is part of a sheath, showing it is composed of longitudinally arranged fibrils. 
intermediate layer which remained with the outer membrane. The outer membrane appeared to be in contact with the dense intermediate layer at certain points (see, for example, Fig. 2).

The outer membrane of cells of both strains was coated with fibrils some 2.0 to $2.5 \mathrm{~nm}$ thick (Figs. I, 2 and 3). The length of the fibrils varied from individual to individual; adjacent organisms in a section have been seen in which one had fibrils $230 \mathrm{~nm}$ long and the other had fibrils only $50 \mathrm{~nm}$ long. The fibrils had a maximum length of $660 \mathrm{~nm}$. In negatively stained preparations, the fibrils appeared to be composed of linear arrays of particles each about 2.0 to $2.5 \mathrm{~nm}$ in diameter, but this may have been due to superposition of background granularity.

\section{Flagella}

The organisms were seen, both in sections and when negatively stained, to be peritrichously flagellate (Fig. 4). The flagella in negatively stained preparations had a maximum length of only $\mathrm{I} \cdot 3 \mu \mathrm{m}$. Flagella of bacteria (e.g. Selenomonads) from the rumen examined under the same conditions were many times longer; although free portions of flagella from the Ovals were found, most had basal hooks attached (Fig. 5), so it is likely that the flagella were not broken. The flagella were some $22 \mathrm{~nm}$ wide in negatively-stained preparations and up to $23 \mathrm{~nm}$ wide in sections. The basal hooks were 100 to $140 \mathrm{~nm}$ long overall and 20 to $22 \mathrm{~nm}$ wide; the surface pattern of their subunits was quite distinct from that of the subunits of the flagellum. Most of the basal hooks bent through an angle of about $90^{\circ}$, but some were semicircular. Each basal hook was attached to the cell envelope by a rod 20 to $30 \mathrm{~nm}$ long and about $9 \mathrm{~nm}$ wide (Figs. 5 and 6), which passed through a double annulus at the level of the outer membrane and terminated in another annular structure at the level of the plasma membrane (Fig. $6 b$ ); the rod must therefore have passed through the dense intermediate layer. The annular structure in the outer membrane was $26 \mathrm{~nm}$ in diameter and about $5 \mathrm{~nm}$ thick, and was therefore very similar to the corresponding part of the basal body in Escherichia coli (DePamphilis \& Adler, 197I). We are not certain about the structure of the annulus in the plasma membrane, but it probably consisted of a single disc.

In strain-2 Ovals the flagella were sheathed (Fig. 7). The sheaths did not normally survive negative staining (with sodium phosphotungstate) unless the specimens were first fixed. In fixed preparations the sheaths extended well beyond the ends of the flagella (Fig. $7 b, c$ ). They consisted of linear arrays of filaments similar in width to the fibrillar coat which covered the whole surface of the outer membrane. The impression given was that the individual filaments making up the sheath extended for its full length, but it is possible that it was formed by the interdigitation of much shorter filaments. In negatively stained preparations the sheaths became flattened, particularly where they extended beyond the ends of the flagella; the diameter of the sheaths where they were not much flattened on the grid was $45 \mathrm{~nm}$, somewhat larger than the figure of 30 to $35 \mathrm{~nm}$ obtained from measurements of electron micrographs of sections (Fig. 7).

\section{Intracellular structures}

Considering the size of the cells, Eadie's Ovals contained remarkably little in the way of specialized intracellular structures. There were thickenings (plaques) on the cytoplasmic side of the plasma membrane, and groups of narrow tubules close to the plasma membrane, which, rarely, had small infoldings. The bulk of the cytoplasm in 'feeding' cells was occupied by glycogen (Orpin, 1973), the remainder containing ribosomes and DNA-like fibrils; there was no discrete nucleus.

The plaques on the cytoplasmic side of the plasma membrane (Fig. 8) were $2 \mathrm{I} \mathrm{nm}$ thick and up to $400 \mathrm{~nm}$ long. They had electron-dense striations approximately $4 \mathrm{~nm}$ wide, 9 to 

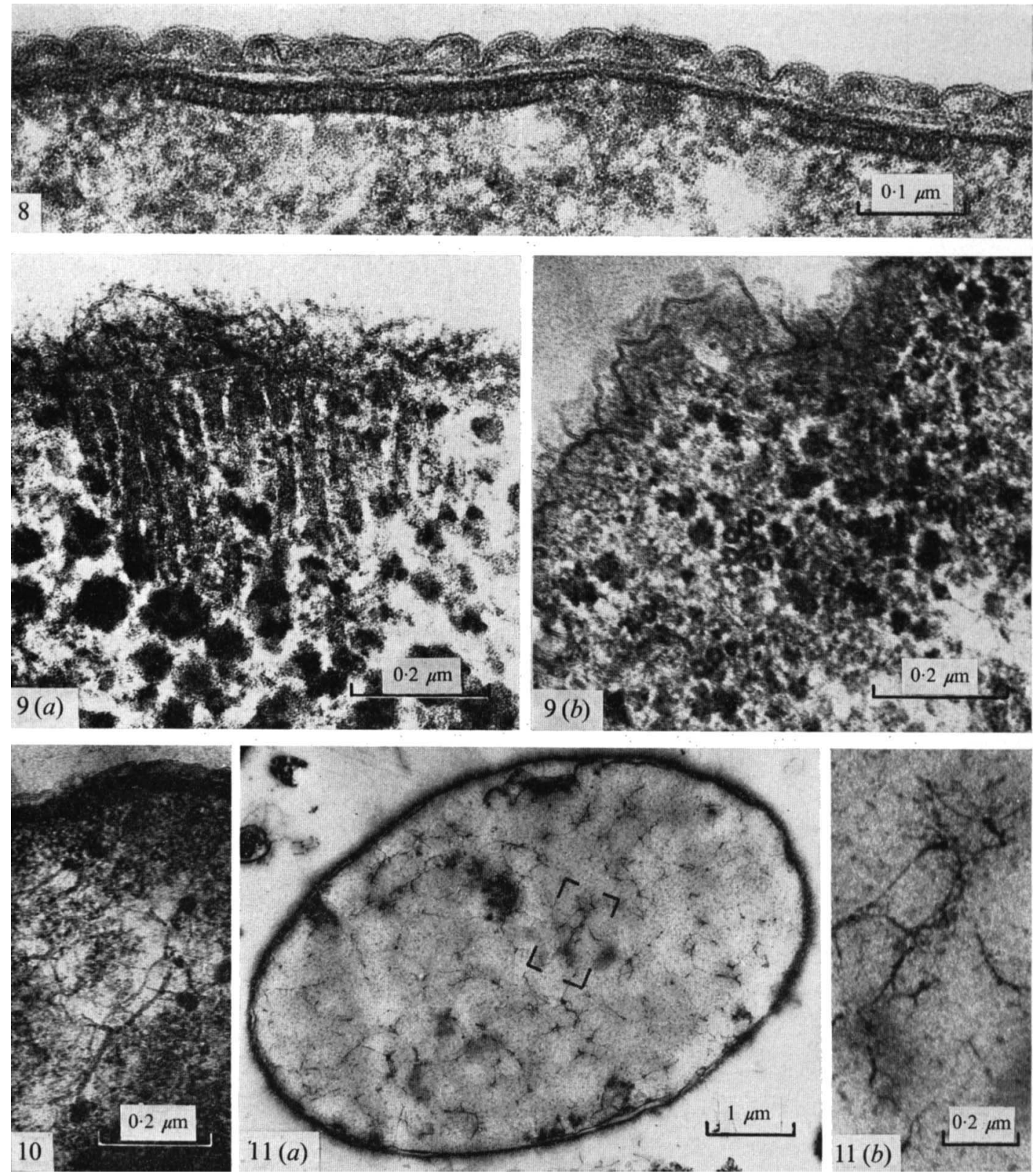

Fig. 8. Section of an Eadie's Oval (strain I) showing the plaques associated with the cytoplasmic side of the inner membrane.

Fig. 9. Sections of Eadie's Ovals (strain I) showing bundles of microtubules, (a) in longitudinal section and $(b)$ in transverse section.

Fig. 10. Section of cortical region of Eadie's Oval (strain 2) showing DNA-like fibres (D).

Fig. I I. Section of a 'starved' Oval. The marked portion of the section shown in $(a)$ is enlarged in $(b)$. 
Io $\mathrm{nm}$ centre-to-centre, perpendicular to the membrane. The plaques were not present in all sections, but up to five might be present in any one section of a cell. There did not seem to be any regularity in their distribution and there was no obvious association with any structure other than the plasma membrane (compare, for instance, the similar structures in Spirillum serpens which are associated with the attachment of the flagella; Murray \& BirchAnderson, 1963).

Occasionally, sections passed through bundles of up to 17 radially-arranged tubules up to $800 \mathrm{~nm}$ long, $25 \mathrm{~nm}$ in external diameter and with a wall about $7.5 \mathrm{~nm}$ thick, which were located just inside the plasma membrane (Fig. 9).

On a dry weight basis, glycogen accounts for up to $60 \%$ of the cell (Orpin, 1972), so it is not surprising that the bulk of the cytoplasmic volume of 'feeding' cells consisted of particles of glycogen (Fig. I). Where the cells were not replete with glycogen there was an apparent cortical region of variable size, free of glycogen. The cortical region contained amorphous, electron-dense material, ribosome-like particles and electron transparent zones which contained DNA-like fibres (Fig. I0). The DNA-like fibres were also distributed throughout the rest of the cytoplasm and were particularly noticeable in cells from cultures incubated in the absence of fermentable carbohydrate for up to $48 \mathrm{~h}$ ('starved' Ovals) in which the glycogen stores were depleted (Fig. I I).

\section{Dividing cells}

Cell division, which we have examined by light microscopy (not illustrated), normally occurred in slightly elongated cells. The first sign was the appearance of a septum dividing the cell into two equal portions. The cell continued to elongate and constricted around the septum. These processes continued until both parts attained an oval shape and then separated to give two equal-sized daughter cells. Very elongated cells were sometimes seen in sections examined with the electron microscope and occasionally they had infoldings of the plasma membrane in the mid-central region which might have been the first definitely recognizable stage in division. The second stage we suppose to be the localized elaboration of the intermediate dense layer which, with the infolding plasma membranes, split the cell into two equal parts.

\section{Effects of treatment with lysozyme and trypsin}

Treatment with lysozyme deformed cells of both strains; the dense intermediate layer was dissolved in places in sections of all cells that we examined (and completely dissolved in some cells) and a few protoplasts were obtained, but the most remarkable effect was the change in the appearance of the layer of fibrils coating the outer membrane (Fig. I2), especially in strain-I cells (Fig. I $2 a, c, e$ ).

In those regions in which the dense intermediate layer was dissolved, the outer membrane was no longer corrugated (Fig. I $2 e, f$ ). Where the dense intermediate layer remained intact, the outer membrane remained corrugated (Fig. I $2 c, d$ ). In both instances in strain-I cells, the fibrous coat formed a compressed dense mat with a prominent cross-banding pattern (Fig. I $2 a, c, e$ ). In strain-2 cells, the fibrous coat, although far more prominent than in the untreated cells, was more loosely arranged and the lateral banding was far less prominent (Fig. $\mathrm{I} 2 b, d, f$ ).

Most strain-2 Ovals treated with trypsin in addition to lysozyme were similar in appearance to those treated with lysozyme alone, but some had less material remaining in the fibrous coat. One preparation of strain-I Ovals treated in this way was examined; these Ovals did not have any fibrous coats. 

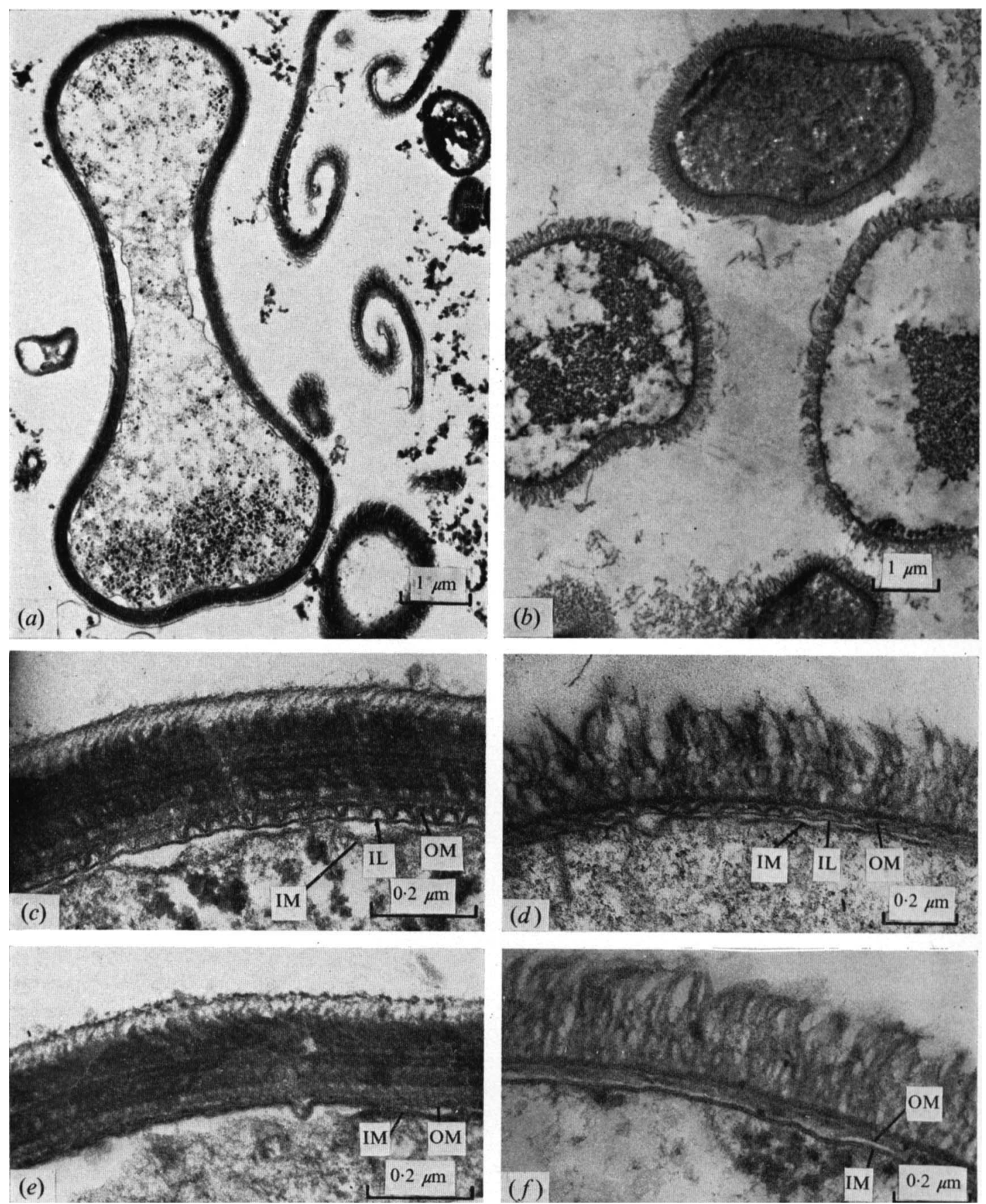

Fig. I2. Sections of Eadie's Ovals treated with lysozyme. $(a),(c),(e)$, strain I, $(b),(d),(f)$, strain 2. $\mathrm{OM}$, outer membrane; IL, dense intermediate layer; IM, inner membrane. 


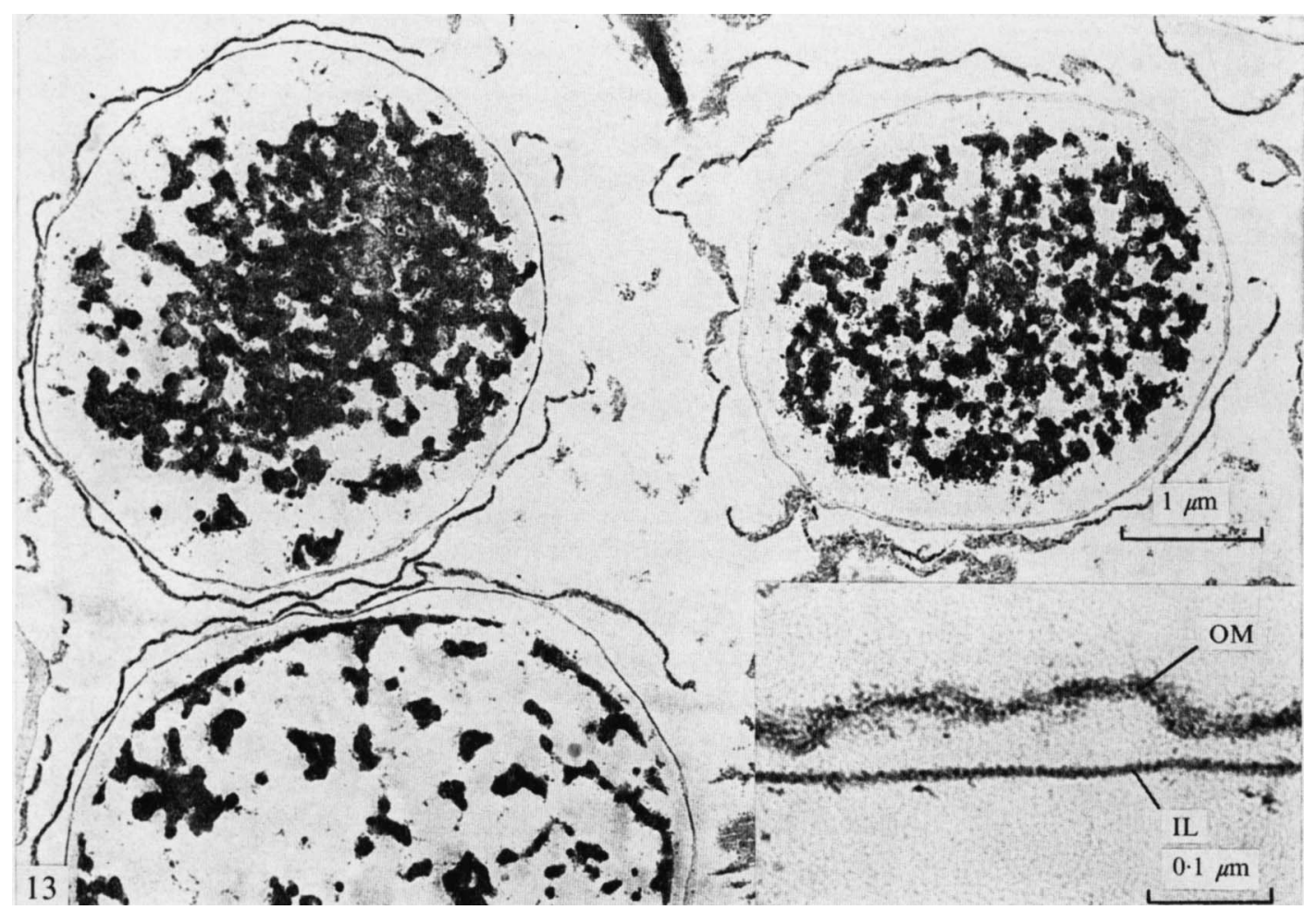

Fig. I3. Sections of cells extracted with chloroform-methanol. The inset shows a portion of the remnant of the cell envelope. OM, outer membrane; IL, dense intermediate layer.

\section{Effects of extraction with chloroform-methanol}

One preparation of strain-2 Ovals was extracted with chloroform-methanol. In most cells, the outer membrane had lost its corrugations and its fibrillar coat; it was partly fragmented, but remained associated with the rest of the cell. The dense intermediate layer was unaffected. The plasma membrane had disappeared and the cell contents were grossly altered in appearance although the DNA-like filaments were still recognizable (Fig. I3).

\section{Effect of extraction with sodium dodecylsulphate or phenol-water}

With the exception of bacteriophage-infected cells (to be described separately), all the Ovals (strain 2) extracted with sodium dodecylsulphate were reduced to sacs consisting of the dense intermediate layer within which the only recognizable structures were particles of glycogen. The contents of Ovals extracted with phenol were reduced to a thin electron-dense cortical layer and the DNA-like nibres enclosed by the dense intermediate layer.

\section{DISCUSSION}

Eadie's Ovals are Gram-negative organisms (Orpin, 1972). They have a three-layered cell envelope structure. The inner and outer layers of the envelope have the appearance typical of membranes and are dissolved by sodium dodecylsulphate, phenol-water and, to a lesser extent, by chloroform-methanol. The intermediate layer between the inner and outer 
membranes is electron-dense in sections; it is not dissolved by phenol-water, detergent or lipid solvent, but is dissolved, at least partially, by lysozyme. Thus, in basic appearance and properties the cell envelope closely resembles that found in many Gram-negative bacteria (see review by Glauert \& Thornley, 1969). The substructure of the flagella, the presence and form of the basal hook and its connexions to the cell envelope are characteristic of bacterial flagella (Glauert, Kerridge \& Horne, 1963; Lowy, I965; Lowy \& Hanson, I965; Hoeniger, van Iterson \& Nijman van Zanten, I966; van Iterson, Hoeniger \& Nijman van Zanten, I966; Abram, Vatter \& Koffler, 1966; Cohen-Bazire \& London, 1967; Abram et al. 1970; DePamphilis \& Adler, 197I). These structural features, coupled with the absence of a discrete nucleus and, additionally, the infection of strain-2 Eadie's Ovals by a virulent bacteriophage (Orpin \& Munn, 1974) confirm, without doubt, that despite their comparatively large size these micro-organisms are bacteria.

Pronounced corrugations of the outer membrane of the kind described here also occur in Spirillum serpens (Murray, 1963) and in Chromobacterium violaceum (D. J. Ellar, unpublished observations; see Salton, I97I, I973), but neither of these have the fibrous coat which is usually so prominent in the Ovals (Figs. I, 2 and 3). We know of no study with other bacteria in which the striking effect of lysozyme on the surface fibrils described here has been observed. We are unable to offer a satisfactory explanation of this phenomenon.

Circular fragments of membrane ('basal bulbs') associated with the basal components of flagella have been observed in a number of lysed preparations of, for instance, Proteus vulgaris (Abram, Koffler \& Vatter, 1965), Proteus mirabilis (Hoeniger et al. 1966), Vibrio metchnikovii and Pseudomonas aeruginosa (Vaituzis \& Doetsch, 1969), but we have seen only one such structure in negatively stained, lysed preparations of Eadie's Ovals. Infoldings of the plasma membrane which we have seen in sections of Ovals, whilst reminiscent of the basal bulbs seen in sections of $P$. mirabilis, do not in fact seem to be associated with flagella.

The bundles of tubules occasionally observed in sections (Fig. 9) were reminiscent of the microtubules which occur in Proteus mirabilis (van Iterson, Hoeniger \& Nijman van Zanten, 1967). The tubules are located near the plasma membrane in both organisms, but the tubules in the Ovals are somewhat larger than those in Proteus.

The structure of the components of the basal bodies in Eadie's Ovals is very similar to that of Spirillum serpens (Cohen-Bazire \& London, 1967) and Escherichia coli (DePamphilis \& Adler, 1971). We are unable to say whether the differences in detail of the basal bodies of these three species are real, or due to differences in the quality (and interpretation) of the electron micrographs.

A variety of bacteria have sheathed flagella, but none so far described appears similar to that of Eadie's Ovals. The flagellar sheaths of Vibrio metchnikovii (Glauert et al. 1963), Bdellovibrio bacteriovorus (Seidler \& Starr, 1968) and Beneckea campbelli (Allen \& Baumann, I 97I) are continuations of the outer membrane. Some of the flagella of Pseudomonas rhodos have what are described as sheaths (Lowy \& Hanson, 1965), but these appear to be surface components of the flagella proper. The flagella of Treponema zuelzerae and another, unidentified bacterium, have true sheaths with characteristic transverse banding patterns (Lowy \& Spencer, 1968); but whilst these, clearly, are not prolongations of the outer membrane, their origin has not been described.

Although Quin's Ovals also have the same characteristic bacterial features as Eadie's Ovals (and their cell walls contain diaminopimelate and muramic acid; Wicken \& Howard, 1967), their size and fine structure are sufficiently different from those of Eadie's Ovals for the two groups to be distinguished easily. The differing structures of the outer membranes, 
the presence or absence of flagella sheaths and their slightly different biochemical activities (Orpin, 1972), show that there are at least two types of Eadie's Ovals present in the rumen of sheep, but the differences do not seem sufficient to justify their separations as two species.

\section{REFERENCES}

Abou Akkada, A. R. \& El-Shazly, K. (1964). Effect of absence of ciliate protozoa from the rumen on microbial activity and growth of lambs. Applied Microbiology r2, 384-390.

Abram, D., Koffler, H. \& VATTER, A. E. (I965). Basal structure and attachment of flagella in cells of Proteus vulgaris. Journal of Bacteriology 9o, I337-I 354.

Abram, D., Mitchen, J. R., Koffler, H. \& VAtTer, A. E. (1970). Differentiation within the bacterial flagellum and isolation of the proximal hook. Journal of Bacteriology ror, 250-26I.

Abram, D., Vatter, A. E. \& Koffler, H. (1966). Attachment and structural features of flagella of certain bacilli. Journal of Bacteriology 91, 2045-2068.

Allen, R. D. \& BaumanN, P. (I97I). Structure and arrangement of flagella in species of the genus Beneckea and Photobacterium fischeri. Journal of Bacteriology 107, 295-302.

Cohen-BAzIRE, G. \& London, J. (1967). Basal organelles of bacterial flagella. Journal of Bacteriology 94, $458-465$.

DePamphilis, M. L. \& Adler, J. (197I). Fine structure and isolation of the hook-basal body complex of flagella from Escherichia coli and Bacillus subtilis. Journal of Bacteriology 105, 384-395.

EADIE, J. M. (1962). The development of rumen microbial populations in lambs and calves under various conditions of management. Journal of General Microbiology 29, 563-578.

Glauert, A. M., KerRidge, D. \& Horne, R. W. (1963). The fine structure and mode of attachment of the sheathed flagellum of Vibrio metchnikovii. Journal of Cell Biology 18, 327-336.

Glauert, A. M. \& THORnLey, M. J. (I969). The topography of the bacterial cell wall. Annual Review of Microbiology 23, 159-198.

Hoeniger, J. F. M., van Iterson, W. \& Nijman van Zanten, E. (1966). Basal bodies of bacterial flagella in Proteus mirabilis. II. Electron microscopy of negatively stained material. Journal of Cell Biology 3r, 603-618.

Hungate, R. E. (1966). The Rumen and its Microbes, p. I3. New York: Academic Press.

VAN ITERSON, W., Hoeniger, J. F. M. \& NiJMAN vaN ZANTEN, E. (1966). Basal bodies of bacterial flagella in Proteus mirabilis. I. Electron microscopy of sectioned material. Journal of Cell Biology 31, 585-60I.

van Iterson, W., Hoeniger, J. F. M. \& Nijman van Zanten, E. (1967). A 'microtubule' in a bacterium. Journal of Cell Biology 32, I-IO.

Lowy, J. (1965). Structure of the proximal ends of bacterial flagella. Journal of Molecular Biology 14, 297-299.

LowY, J. \& Hanson, J. (1965). Electron microscope studies of bacterial flagella. Journal of Molecular Biology II, 293-313.

LOWY, J. \& SPENCER, M. (1968). Structure and function of bacterial flagella. Symposia of the Society for Experimental Biology 22, 21 5-236.

McGaughey, C. A. \& Sellers, K. C. (1948). Microflora of the rumen. Nature, London I6I, IoI4-10i5.

MurRaY, R. G. E. (1963). On the cell wall structure of Spirillum serpens. Canadian Journal of Microbiology 9, $381-392$.

Murray, R. G. E. \& Birch-Anderson, A. (1963). Specialised structure in the region of the flagella tuft in Spirillum serpens. Canadian Journal of Microbiology 9, 393-40I.

ORPIN, C. G. (1972). The culture of the rumen organism Eadie's Oval in vitro. Journal of General Microbiology 70, $321-329$.

Orpin, C. G. (1973). The intracellular polysaccharide of the rumen bacterium Eadie's Oval. Archiv für Mikrobiologie 90, 247-254.

OrPIN, C. G. \& MUNN, E. A. (I974). The occurrence of bacteriophages in the rumen and their influence on rumen bacterial populations. Experientia 30, 1018-1020.

QUIN, J. I. (1943). Studies on the alimentary tract of Merino sheep in South Africa. VII. Fermentation in the forestomachs of sheep. Onderstpoort Journal of Veterinary Science and Animal Industry 18, 9 I-I I 2.

Salton, M. R. J. (1971). The bacterial membrane. In Biomembranes, vol. I, pp. I-65. Edited by L. A. Manson. New York and London: Plenum Press.

Salton, M. R. J. (1973). Structure and function of the bacterial cell wall. In The Generation of Subcellular Structures, pp. 235-262. Edited by R. Markham, J. B. Bancroft, D. R. Davies, D. A. Hopwood and R. W. Horne. Amsterdam: North-Holland. 
SeIdler, R. J. \& StaRr, M. P. (1968). Structure of the flagellum of Bdellovibrio bacteriovorus. Journal of Bacteriology 95, 1952-1955.

VAITUZIS, Z. \& DOETSCH, R. N. (I969). Relationship between cell wall, cytoplasmic membrane and bacterial motility. Journal of Bacteriology 100, 5I 2-52 I.

WARNER, A. C. I. (I962). Some factors influencing the rumen microbial population. Journal of General Microbiology 28, 129-146.

WARNER, A. C. I. (I966). Diurnal changes in the concentrations of micro-organisms in the rumens of sheep fed limited diets once daily. Journal of General Microbiology 45, 2 I 3-235.

van Der Westhuizen, G. C. A., Oxford, A. E. \& Quin, J. I. (1950). Studies on the alimentary tract of Merino sheep in South Africa. XVI. On the identity of Schizosaccharomyces ovis. I. Some yeast-like organisms isolated from the rumen contents of sheep fed on a lucerne diet. Onderstpoort Journal of Veterinary Science and Animal Industry 24, I I9-124.

WiCKen, A. J. \& HowARD, B. H. (I967). On the taxonomic status of 'Quin's Oval' organisms. Journal of General Microbiology 47, 207-2 I I.

Woodcock, H. M. \& LAPAGE, G. (I9I3). On a remarkable type of protistan parasite. Quarterly Journal of Microscopical Science 59, 43 I-458. 